\title{
GAMBARAN PENGETAHUAN SUAMI TENTANG ALAT KONTRASEPSI KB KONDOM DI DUSUN SAPANANG KECAMATAN KAJANG KABUPATEN BULUKUMBA
}

\author{
Mudyawati Kamaruddin $^{1 *}$, Nita Ariani Nur ${ }^{2}$, Sukmawati $^{3}$ \\ ${ }^{1}$ Program Studi Kebidanan, Akademi Kebidanan Tahirah Al Baeti Bulukumba, Sulawesi Selatan \\ ${ }^{2}$ Program Studi Kebidanan, Akademi Kebidanan Tahirah Al Baeti Bulukumba, Sulawesi Selatan \\ ${ }^{3}$ Pusat Kesehatan Masyarakat Kajang, Kajang Bulukumba Sulawesi Selatan Universitas \\ *Corresponding author: Telp: +628114120603, email: mudya07@gmail.com
}

\begin{abstract}
ABSTRAK
Penggunaan kontrasepsi kondom masih rendah dan kurang dipilih oleh suami dalam menekan laju pertumbuhan penduduk yang semakin meningkat. Tujuan penelitian ini adalah mengetahui gambaran pengetahuan suami tentang pemakaian kondom di Desa Sapanang Kecamatan Kajang Kabupaten Bulukumba. Jenis Penelitian ini adalah penelitian deskriptif. Jumlah sampel yang didapatkan sebanyak 30 responden yang memakai alat kontrasepsi KB kondom. Penelitian ini menunjukkan hasil bahwa pengetahuan suami tentang kondom di Dusun sapanang Kec. Kajang Kab. Bulukumba yaitu kategori baik (3,4\%), cukup (46,6 \%), dan kurang $(50 \%)$. Pengetahuan suami berdasarkan pengertian tentang kondom dalam kategori baik (3,3\%), cukup (26,7\%), dan kurang $(70,0 \%)$. Pengetahuan suami berdasarkan kelebihan kondom yaitu kategori baik (3.4\%), kurang (96.6\%) dan cukup (0.0\%). Pengetahuan suami berdasarkan kekurangan kondom yaitu kategori baik (46,6\%), cukup (10\%), dan kurang $(43,4 \%)$. Pengetahuan suami berdasarkan efek samping tentang kondom yaitu kategori baik $(3,4 \%)$, cukup (30\%), dan kurang $(66,6 \%)$. Kesimpulan penelitian ini adalah sebagian besar pengetahuan suami tentang alat kontrasepsi kondom masih kurang. Selain itu, pengetahuan suami terhadap pengertian kontrasepsi kondom, tentang kelebihan kontrasepsi kondom dan tentang efek samping terhadap kondom juga masih berkategori kurang. Akan tetapi, mayoritas pengetahuan para suami tentang kekurangan kondom adalah berkategori baik.
\end{abstract}

Kata kunci : Pengetahuan, Pendidikan, Kondom

\section{ABSTRACT}

The use of condom contraceptives is still low and is not chosen by husbands in suppressing the increasing population growth rate. The purpose of this study was to describe the husband's knowledge of condom use in Sapanang Village, Kajang District, Bulukumba Regency. This type of research is a descriptive study. The number of samples obtained were 30 respondents who used condom contraceptives. This study shows the results that the husband's knowledge of condoms in Dusun sapanang Kec. Kajang Kab. Bulukumba is in the good category (3.4\%), sufficient (46.6\%), and poor (50\%). Husband's knowledge based on the understanding of condoms in the good category (3.3\%), sufficient (26.7\%), and less (70.0\%). Husband's knowledge based on the advantages of condoms, namely the good category (3.4\%), poor (96.6\%) and sufficient (0.0\%). Husband's knowledge based on condom deficiency is good (46.6\%), sufficient (10\%), and poor (43.4\%). Husband's knowledge based on the side effects of condoms was good (3.4\%), sufficient (30\%), and poor (66.6\%). The conclusion of this study is that most of the husband's knowledge about condom contraception is still lacking. In addition, the husband's knowledge of the definition of condom contraception, the advantages of condom contraception and the side effects of condoms is also in the poor category. However, the majority of husbands' knowledge about condom deficiency is in the good category.

Keywords: Knowledge, Education, Condoms 


\section{PENDAHULUAN}

Menurut WHO (Whorld Health organization) Keluarga Berencana (KB) adalah tindakan pasangan suami istri untuk menghindari kehamilan yang tidak diinginkan, mendapatkan kelahiran yang memang sangat diinginkan, mengatur interval di antara kehamilan dalam hubungan dengan umur suami istri serta menentukan jumlah anak dalam keluarga. ${ }^{1}$

Indonesia masih memiliki masalah tentang kependudukan yang belum bisa teratasi dengan baik, misalnya laju pertumbuhan penduduk yang semakin meningkat yang menyebabkan kepadatan penduduk menurut Hatta., ${ }^{3}$ Permasalahan lain yang sampai saat ini masih dihadapi adalah pembangunan bidang kependudukan dan keluarga berencana masih sangat kurang seperti sosialisasi kontrasepsi hal ini dapat dilihat dari kurangnya pria yang menggunakan kontrasepsi, kurangnya pengetahuan pasangan suami istri tentang $\mathrm{KB}$, dan masih belum sinergisnya kebijakan pengendalian penduduk. ${ }^{4}$

Macam-macam metode kontrasepsi tersebut adalah Intra Uterine Devices (IUD), implant, suntik, kondom, metode operatif untuk wanita (tubektomi), metode operatif untuk pria (vasektomi). Diantara macammacam metode kontrasepsi, kondom merupakan metode kontrasepsi yang dianggap lebih aman, alat kontrasepsi yang cukup efektif dan mudah didapat ${ }^{5}$. Selain itu, fungsi kondom dapat membantu dan melindungi akseptor terhadap beberapa infeksi menular seksual termasuk HIV. Sedangkan kerugian memakai kondom ialah cara penggunaan yang tidak benar menyebabkan kondom bisa copot atau lepas, selain itu kenyamanan dalam memakainya sangat kurang dirasakan pada saat berhubungan seksual.

Menurut data dari sulawesi selatan tahun 2012, persentase tertinggih alat / cara KB aktif adalah suntikan $(46,49 \%)$ kemudian pil $(31,35 \%)$ implant $(8,95 \%)$ obat vagina $(0,03 \%)$ dan lainnya $(0,05 \%)$. Sedangkan persentase penggunaan kontrasepsi bagi peserta KB baru yang terbanyak selama tahun 2012 tersebut masing masing suntikan $(46,52 \%)$ pil $31,25 \%)$ kondom $(9,70 \%)$ implant $(7,40 \%)$ IUD $(4,01 \%)$ MOW $(0,88 \%)$ MOP $(0,21 \%)$ obat vagina $(0,00 \%)$ dan lainnya $(0,03 \%)$ peserta. $^{6}$

Data dari Dinas Kesehatan Kabupaten Bulukumba, pada tahun 2015 jumlah akseptor KB aktif mencapai 44.057 peserta atau $58,50 \%$ peserta untuk pemakai kontrasepsi. Pengguna paling banyak adalah metode suntikan sebesar 31.289 peserta atau $71,01 \%$ dari jumlah akseptor, sedangkan pengguna pil sebanyak 8.873 peserta atau $20,13 \%$, pengguna kondom sebanyak 1628 peserta atau 3,69\%, pengguna intra uterine devices (IUD) sebanyak 779 peserta atau $1,76 \%$, pengguna implan sebanyak 1364 peserta atau 3,09\% peserta, serta akseptor $\mathrm{KB}$ dengan masing masing metode operasi wanita (MOW) sebanyak 105 peserta atau $0,23 \%$,metode operasi pria sebanyak 19 peserta atau $0,04 \%$ peserta. $^{7}$

Dari data di atas menunjukkan bahwa penggunaan kontrasepsi kondom masih rendah dan kurang dipilih oleh suami. Berdasarkan alasan di atas, maka peneliti tertarik untuk melakukan penelitian tentang gambaran pengetahuan suami tentang alat kontrasepsi KB kondom di Desa Sapanang Kec. Kajang Kabupaten Bulukumba.

\section{METODOLOGI}

Jenis penelitian yang digunakan adalah penelitian deskriptif. Penelitian ini akan dilakukan di Dusun Sapanang Kecamatan Kajang Kabupaten Bulukumba selama 2 bulan mulai tanggal 20 april sampai dengan tanggal 20 juni 2016.

Jumlah sampel yang didapatkan sebanyak 30 responden yang memakai alat kontrasepsi KB kondom. Teknik pengumpulan data dengan menggunakan kuisioner. Teknik sampling yang digunakan yaitu teknik Purposive sampling yaitu teknik pengambilan sampel secara sengaja sesuai dengan kriteria inklusif. Kriteria inklusif penelitian yaitu suami bisa membaca dan menulis, bersedia menjadi responden dan ada pada saat penelitian. 
Analisis data dilakukan secara deskriptif yang di sajikan dalam bentuk tabel frekuensi persentase. Adapun rumus frekuensi persentase yaitu sebagai berikut (Riwidkdo, 2010:13) :

$$
\mathrm{P}=\frac{\mathrm{F}}{\mathrm{N}} \times 100 \%
$$

Keterangan :

P : Presentase

F : Frekuensi

N : Jumlah data (Riwidkdo, 2010:13)

\section{HASIL DAN PEMBAHASAN \\ HASIL}

Tabel 1 dapat diketahui umur responden mayoritas adalah kelompok umur 25-30 tahun sebanyak 16 responden (57,3\%). Sedangkan kelompok yang berumur 18-24 tahun sebanyak 14 responden $(46,7 \%)$.

Tabel 1. Karakteristik responden berdasarkan umur

\begin{tabular}{|c|c|c|c|}
\hline $\mathrm{NO}$ & $\begin{array}{l}\text { Umur } \\
\text { (tahun) }\end{array}$ & (n) & $(\%)$ \\
\hline 1 & $18-24$ & 14 & 46,7 \\
\hline \multirow[t]{2}{*}{2} & $25-30$ & 16 & 57,3 \\
\hline & Total & 30 & 100 \\
\hline
\end{tabular}

responden yang dominan adalah tingkat SD dan SMA yaitu sebanyak 11 (36,7\%), sedangkan pendidikan tingkat SMP hanya 8 responden $(26,6 \%)$.

Tabel 2. Distribusi frekuensi responden berdasarkan pendidikan

\begin{tabular}{cccc}
\hline NO & Pendidikan & $(\mathrm{n})$ & $(\%)$ \\
\hline 1 & SD & 11 & 36,7 \\
2 & SMP & 8 & 26,6 \\
3 & SMA & 11 & 36,7 \\
\hline & Total & 30 & $100 \%$ \\
\hline
\end{tabular}

Tabel 3 diketahui bahwa status pekerjaan responden yang dominan adalah petani sebanyak 23 responden (76,7\%), sedangkan wiraswasta hanya sebesar 7 responden $(23,3 \%)$.
Tabel 3. Distribusi frekuensi responden berdasarkan pekerjaan

\begin{tabular}{cccc}
\hline No & Pekerjaan & $(\mathrm{n})$ & $(\%)$ \\
\hline 1 & Petani & 23 & 76,7 \\
2 & Wiraswasta & 7 & 23,3 \\
\hline & Total & 30 & $100 \%$ \\
\hline
\end{tabular}

Tabel 4 dapat diketahui bahwa deskripsi pengetahuan responden tentang kondom di Dusun Sapanang Kec. Kajang Kab. Bulukumba terbagi dalam 3 kategori, yaitu kategori baik sebanyak 1 responden $(3,4 \%)$, kategori cukup yaitu 14 responden (46,6 \%), dan kategori kurang adalah 15 responden $(50 \%)$.

Tabel 4. Distribusi frekuensi pengetahuan responden tentang kondom di Dusun Sapanang Kec. Kajang kab. Bulukumba

\begin{tabular}{|c|c|c|c|c|}
\hline \multirow[b]{2}{*}{ No } & \multirow[b]{2}{*}{ Klasifikasi } & \multirow{2}{*}{$\begin{array}{c}\text { Kriteria } \\
\text { objektif } \\
(\%)\end{array}$} & \multicolumn{2}{|c|}{ Respon } \\
\hline & & & $\mathrm{F}$ & $\%$ \\
\hline 1 & Baik & $76-100$ & 1 & 3,4 \\
\hline 2 & Cukup & $56-75$ & 14 & 46,6 \\
\hline 3 & Kurang & $\leq 56$ & 15 & 50 \\
\hline & Total & & 30 & $100 \%$ \\
\hline
\end{tabular}

Tabel 5 dapat diketahui bahwa deskripsi pegetahuan responden berdasarkan pengertian tentang kondom di Dusun Sapanang Kec. Kajang Kab. Bulukumba dalam kategori baik sebanyak 1 responden $(3,3 \%)$, kategori cukup sebanyak 8 responden $(26,7 \%)$, dan kategori kurang sebanyak 21 responden $(70,0 \%)$.

Tabel 5. Distribusi frekuensi pengetahuan responden berdasarkan pengertian tentang kondom di Dusun Sapanang Kec. Kajang Kab. Bulukumba

\begin{tabular}{cccc}
\hline No & Kategori & (n) & $(\%)$ \\
\hline 1 & Baik & 1 & 3,3 \\
2 & Cukup & 8 & 26,7 \\
3 & Kurang & 21 & 70,0 \\
\hline & Total & 30 & $100 \%$ \\
\hline
\end{tabular}

Tabel 6 tersebut dapat diketahui bahwa deskripsi pengetahuan responden 
berdasarkan kelebihan kondom terdistribusi dalam 3 kategori yaitu baik sebanyak 1 responden (3.4\%), kurang sebanyak 29 responden $(96.6 \%)$ dan tidak ada satu pun yang berkategori cukup (0.0\%).

Tabel 6. Distribusi frekuensi pengetahuan responden tentang kelebihan kondom di Dusun Sapanang Kec. Kajang Kab. Bulukumba.

\begin{tabular}{cccc}
\hline No & Kategori & $(\mathrm{n})$ & $(\%)$ \\
\hline 1 & Baik & 1 & 3,4 \\
2 & Cukup & 0 & 0,0 \\
3 & Kurang & 29 & 96,6 \\
\hline & Total & 30 & $100 \%$ \\
\hline
\end{tabular}

Tabel 7 dapat diketahui bahwa deskripsi pengetahuan responden berdasarkan kekurangan kondom terdistribusi dalam 3 kategori yaitu baik sebanyak 14 responden $(46,6 \%)$, cukup sebanyak 3 responden $(10 \%)$, dan kurang sebanyak 13 responden $(43,4 \%)$.

Tabel 7. Distribusi frekuensi pengetahuan responden tentang kekurangan kondom di Dusun Sapanang Kec. Kajang Kab. Bulukumba.

\begin{tabular}{cccc}
\hline No & Kategori & $(\mathrm{n})$ & $(\%)$ \\
\hline 1 & Baik & 14 & 46,6 \\
2 & Cukup & 3 & 10 \\
3 & Kurang & 13 & 43,3 \\
\hline & Total & 30 & $100 \%$ \\
\hline
\end{tabular}

Tabel 8 dapat diketahui bahwa pengetahuan responden berdasarkan efek samping tentang kondom terdistribusi dalam 3 kategori yaitu baik sebanyak 1 responden $(3,4 \%)$, cukup sebanyak 9 responden $(30 \%)$, dan kurang sebanyak 20 responden $(66,6 \%)$.

Tabel 8. Distribusi frekuensi pengetahuan responden tentang efek samping kondom di Dusun Sapanang Kec. Kajang Kab. Bulukumba.

\begin{tabular}{cccc}
\hline No & Kategori & (n) & $(\%)$ \\
\hline 1 & Baik & 1 & 3,4 \\
\hline 2 & Cukup & 9 & 30 \\
\hline 3 & Kurang & 20 & 66,6 \\
\hline & Total & 30 & $100 \%$ \\
\hline
\end{tabular}

\section{PEMBAHASAN}

Diantara macam-macam metode kontrasepsi, kondom merupakan metode kontrasepsi yang dianggap lebih aman, alat kontrasepsi yang cukup efektif dan mudah didapat. Selain itu, fungsi kondom dapat membantu dan melindungi akseptor terhadap beberapa infeksi menular seksual termasuk HIV. Akan tetapi, penggunaan kontrasepsi kondom masih rendah dan kurang dipilih oleh suami sebagai responden dalam penelitian ini. Untuk itu, penelitian ini dilakukan untuk mendapatkan gambaran pengetahuan suami tentang alat kontrasepsi KB kondom di Desa Sapanang Kec. Kajang Kab. Bulukumba.

Berdasarkan hasil penelitian ini, pengetahuan responden dalam hal ini para suami tentang kondom menunjukkan sebagian besar pengetahuan mereka berada pada kategori kurang (Tabel 4). Begitu pula pengetahuan suami terhadap pengertian kondom (Tabel 5). Hal ini kemungkinan disebabkan oleh faktor pendidikan para suami akseptor KB tersebut mayoritas berpendidikan sekolah dasar dan menengah atas (Tabel 2). Menurut Notoadmodjo (2012), Pendidikan seseorang mempengaruhi cara pandangnya terhadap diri dan lingkungan ${ }^{8}$. Oleh karena itu, akan berbeda orang yang berpendidikan rendah dalam menyikapi proses dan berinteraksi. Semakin tinggi tingkat pendidikan seseorang, maka akan mudah menerima informasi sehingga semakin banyak pula pengetahuan yang dimilikinya pendidikan yang kurang akan menghambat pengembangan sikap seseorang terhadap nilai-nilai baru yang diperkenalkan.

Adapun hasil pengetahuan suami tentang kelebihan kontrasepsi kondom, juga sebagian besar berada pada kategori kurang (Tabel 6), hal ini mungkin dapat dihubungkan dengan sikap para suami terhadap kondom yang mendominasi tentang sisi negatif atau kekurangannya, sehingga tidak ada motivasi untuk mengetahui kelebihan kontrasepsi kondom. Selain itu, kurangnya informasi yang diperoleh dari petugas kesehatan, selain hampir semua kerja para suami adalah petani (Tabel 3) yang sehari-harinya sibuk dengan 
pekerjaannya di kebun atau di sawah dibandingkan dengan menghadiri pertemuan konseling di puskesmas atau di balai desa apabila terdapat kegiatan tentang alat dan metode kontrasepsi. Hal ini sejalan dengan hasil pengetahuan suami terhadap kekurangan kondom, dimana mayoritas pengetahuan para suami tentang kekurangan kondom didominasi oleh kategori baik (Tabel 7). Artinya, sikap para suami untuk kurang berminat pada alat kontrasepsi kondom dikarenakan telah mengetahui kekurangan pada kontrasepsi ini, yang mungkin diperoleh dari orang-orang yang terdahulu menggunakan kondom. Salah satu kekurangan kondom adalah ketidaknyamanan dalam pemakaiannya pada saat berhubungan seksual. ${ }^{9}$

Berbeda dengan pengetahuan suami tentang efek samping terhadap kondom. Hampir semua para suami kurang mengetahui tentang efek samping yang dihasilkan saat penggunaan alat kontrasepsi kondom (Tabel 8). Kemungkinan hal ini disebabkan oleh kurang mengikuti konseling tentang alat kontrasepsi dikarenakan tugas sehari-hari sebagai petani dan mungkin juga dikarenakan pendidikan yang mayoritas pada tingkat yang rendah sehingga kurang memahami tentang informasi yang disampaikan pada saat penyuluhan kontrasepsi.

\section{KESIMPULAN}

Berdasarkan hasil penelitian yang telah dilakukan dengan judul gambaran pengetahuan suami tentang penggunaan kontrasepsi KB kondom di Desa Sapanang Kecamatan Kajang Kabupaten Bulukumba, maka dapat disimpulkan bahwa sebagian besar pengetahuan suami tentang alat kontrasepsi kondom masih kurang. Selain itu, pengetahuan suami terhadap pengertian kontrasepsi kondom, pengetahuan suami tentang kelebihan kontrasepsi kondom dan pengetahuan suami tentang efek samping terhadap kondom yang juga masih berkategori kurang. Akan tetapi, mayoritas pengetahuan para suami tentang kekurangan kondom adalah berkategori baik.

\section{DAFTAR PUSTAKA}

1. Suratun S, Tien H, Rusmiati S. Pelayanan Keluarga Berencana Dan Pelayanan Kontrasepsi. Trans Info Media; 2008.

2. Hidayati K, Listyani E. Upaya Konselor untuk Meningkatkan Kemandirian Belajar Siswa. Majalah Dinamika Guru. 2012.

3. Kamaruddin M, Sumarni, Ganie AH, et al. Faktor-Faktor yang Berhubungan dengan Kurangnya Minat Ibu Terhadap Penggunaan Metode Kontrasepsi Implant di Wilayah Puskesmas Ponre Kecamatan Gantarang Kabupaten Bulukumba. 2020;1(2):156-166.

4. BKKBN. Standar Pelayanan Minimal (SPM) Bidang Keluarga Berencana dan Keluarga Sejahtera di Kabupaten/Kota. Published online 2010.

5. Usmia S, Wahyuni S, Kamaruddin M, Misriyani. Deskripsi Pengetahuan Ibu Tentang KB Suntik 3 Bulan (Depo Progestin) di Puskesmas BontoBahari Bulukumba. 2020;2(2):179-186.

6. Kementerian Kesehatan RI. Profil Kesehatan Provinsi Sulawesi Selatan Tahun 2012. Published online 2012.

7. Dinas Kesehatan Kabupaten Bulukumba. Profil Kesehatan Kabupaten Bulukumba Tahun 2014. Published online 2015.

8. Notoadmodjo S. Metode Penelitian Kesehatan. PT. Rineka Cipta; 2012.

9. Аyu. Ilmu Kebidanan Penyakit. EGC; 2006. 